\title{
Homeless population and the city: an analysis of the re-signification of urban spaces
}

População de rua e cidade: uma análise da ressignificação dos espaços urbanos

Lucas Eduardo Lima Dantas [I]

\begin{abstract}
The investigations proposed in this paper intend to reflect on the relationship between the Population in Street Situation (PSS) and urban space, taking into account the meanings and conflicts produced on the urban fabric by this group. It will be sought, therefore, to understand the way in which the individual relates to space through his walk and the new meanings he produces on the environment he occupies. To understand this logic, we use a historical discussion to understand the urban model of the present city, from its spatial disposition to the emergence of its social problems.
\end{abstract}

Keywords: people in street situation; everyday life; city. urbanity; imaginary.

\section{Resumo}

As investigações propostas neste artigo pretendem refletir acerca da relação entre a População em Situação de Rua (PSR) e o espaço urbano, levando em consideração as significações e os conflitos produzidos sobre o tecido urbano por esse grupo. Buscar-se-á, portanto, entender a maneira como o indivíduo se relaciona com o espaço através da sua caminhada e das novas significações que produz sobre o ambiente que ocupa. Para entender tal lógica, recorre-se a uma discussão histórica para entendermos o modelo urbano da cidade atual, desde sua disposição espacial ao surgimento de seus problemas sociais.

Palavras-chave: população de rua; cotidiano; cidade; urbanidades; imaginário. 


\section{Introduction}

This article has, as a starting point, the need to reflect on the relationship between the people in street situation and the city. To problematize their condition on the public street, to analyze their action in this territory of common use. Therefore, it is clear, in this study, that the urban space and the people in the street are directly related through the uses that this group makes on the space beyond its media representation.

The city as we conceive it today is the result of a series of historical transformations that resulted in a symbolic production of the society models adopted by the civilization over time. A space delimited by culture, nature, politics, economics, in short: the city, great and always in a reconstruction process, of meanings production from the process of social interaction.

Cities are their own historical formations, each one with its own individuality, they represent the specific culture of its time, as Peter Hall will convincingly demonstrate in his book Cities in civilization (1988). Hall recalls that today cities, as cultural, economic and political centers, can replace the reality of the concept of Nation/State. (Freitag, 2012, p. 23)

The current urban model can be understood as the result of a process of reframing the way of living, adopted by the different cultures created by the man living in society. If today we live in houses and apartments and move through the streets in an organized manner, all of this is justified by the process of historical convention that the city spaces went through. Social convention influenced, from the last centuries to the present days, by an urbanistic current of rationalist aspects, in which each social agent has its function and space very well delineated by an implicit social logic: where to live, where to work, where to move on foot or by car, where to park and where to go on.

However, as a counterpoint to this view, as it will be presented throughout this narrative, not everything nor everyone is stuck and obliged to follow an assumed logic, challenging to live the city in a free way, without defined paths or pre-established places, having their references built by collective production and kept in the place memory. A effervescent, vivid production, reinventing the way of living and having the right to the city.

Referring to this memory about the past that constitutes the production of the city's present, in this process of constant repetition, Michel de Certeau points out that

\begin{abstract}
The renewed "old stones" become places of transit between ghosts of the past and the imperatives of the present. They are passages on multiple borders that separate times, groups and practices. In the manner of public squares where different streets flow, the restored buildings constitute, in a historical way and no longer geographic, exchanges between strange memories.
\end{abstract} (Certeau, 2012, p. 194)

It is through the reverse path of urban rationalism, through the "invisible" and "unpredictable" bias, that we will carry forward our discussions about space, much more linked to its variability of meanings produced and to the individual trajectory that each individual traces for themselves, reconfiguring the norms of that space. 
It can be understood that the city in contemporary times as a space that seeks more fluidity in its processes every day, in parallel to the search for greater productivity in less time. As the modern city was, seen as a space of fluidity and speed, the city now has a much more accentuated consumption bias.

Within this discussion about the urban space of cities, it is interesting to pay attention to the invisible force, responsible for actions and events, a force that is incessant, that circulates over all space and that is present in the practice of urban passersby: the quotidian.

It can be said that the quotidian is what is given to us each day, which is present in our routines, actions. The force that presses us over space and makes us shock about the individuals through interactions and relationships day after day. It would be the weight of life that we always assume when waking up daily to do our chores. As Certeau points out, it would also be

[...] the struggle of living, or living in this or another condition, with this fatigue, with that desire. Quotidian is what keeps us close, from the inside. It is a story halfway through ourselves, almost in retreat, sometimes veiled, this "world of memory" must not be forgotten according to Peguy's expression. It is a world that we deeply love, olfactory memory, memory of places, memory of the body, of childhood gestures, of pleasures. Perhaps it is not useless to underline the importance of mastering this "irrational" history, or this "nonhistory", as A. Dupont says, what interests the historian of everyday life is the invisible. (Ibidem, p. 31)
As a starting point for the discussions presented here, the relations between space, identity and memory will be addressed. The way that the individual relates to the urban memory also contributes to build his own identity - taking into account the collective production accumulated by social memory over the inhabited space - as well as the imagery produced as a result of these interactions.

Subsequently, it will be needed to have attention to the subject's practical role within everyday's logic. The concepts developed about the everyday report will be highlighted, seeing it as an element of clear importance for the meaning of these spaces. Calling attention to the proper sense that delimits the relations that may be unfolded over these places.

After these reflections on what this urban space is as a model of fruition - which, at the same time, demonstrates the wonder and terror of inhabiting the urban space -, we will make a rescue to its bases located in the 19th century, in which we can find the references for the construction of this modern that today focuses on the contemporary. To investigate the layout of this space, regarding its urban and social organization, seeking to understand the origins of processes such as gentrification and segregation of the most disadvantaged groups in the most valued areas of the city. Along with this investigation, attention will also be paid to the formation of public and private concepts, which are very important for understanding the establishment of this urban planning. These analyzes are about the urban space in Rio, which has references to modern European, with French bases. 
In conclusion, a reflection on the role of the street population on the urban environment, questioning its place of enunciation within the social structure, in order to try to understand how it is enunciated, when inhabiting the public space of the urban environment, resulting in the construction of a new logic of space, a new "private" map of the inhabited territory. What we will try to demonstrate with these considerations is that, although the homeless person is subjected to only certain spaces in the city, which, generally are the spaces excluded from common coexistence, are the remains of the urban, such as marquees or viaducts, silenced in their speech, that they can re-signify as a daily tactic (Certeau, 2014), based on their presence and practice.

\section{City spaces, Identity and Memory: the disposition of agents on the urban space}

An environment of fruition, traffic and continuous production of meaning, living in the city today can be understood as a rich and varied anthropological experience. Urbanity, a striking feature in the space of cities, constitutes the symbolic notion that social agents make about this territory, which are spaces, whether public or private.

To reflect on the constitution of these spaces is, first of all, to pay attention to the collective production of the identity and historical aspects of individuals. Model of collective production that unfolds from everyday practice: dwelling, celebrations, extraordinary events, routine, interactions, all this constitutes this urban panorama that we intend to address here. The city is the product of constant production in everyday life, and the practical act of signifying the spaces of the city is also an identity action that leaves its mark, remains in memory (Pesavento, 2008).

From the practice of everyday life, from what is ordinary, common, it is that the meanings about spaces are being conceived. The socially constructed repertoire creates new symbols and codes to be adopted by society, reformulating the way of living on and understanding the relationships that unfold in this urban area.

According to Pesavento (ibidem), These meanings produce a qualified urban territory, always in reinvention, according to the common elements of the daily life of the individuals who participate in this incessant sharing.

These spaces, endowed with meaning, make each city a qualified urban territory, integrating this symbolic community of meanings, which is called the imaginary. More than spaces, that is, extension of surface, they are territories, because they are appropriated by the social. (Ibidem, p. 3)

The author draws attention to the imaginary, the result of the accumulation of symbols, actions and images that are produced about this urban environment and used as a reference for situations or new meanings that may arise from everyday actions. Here, specifically, it is about the 
imaginary, shared vision of individuals about a specific territory, based on the relationships that have developed there over a historical period.

When entering the field of discussions about the imaginary, it is important to highlight opinions about the theme. Maffesoli (2001) works with approaches based on the analysis of everyday relationships, forming a sociology of the sensitive. Giving relevant importance to the subject's experience, the author highlights the group relations over a given space, based on the collective imaginary: "The imaginary is something that surpasses the individual, that permeates the collective or, at least, part of the collective " (Ibidem, P. 76). Therefore, we can understand imaginary as a symbolic category shared and socially constructed, through everyday events and the substrate produced by social relations between different groups.

Maffesoli, presenting a breaking point with the definition of some other authors who approach the theme, argues that, being an element of collective construction, the imaginary cannot be fragmented, shared, taking into account the cultural and symbolic traits of each subject within the social core.

One can speak of "my" imaginary or "yours", but when one examines the situation of those who speak this way, one sees that their imaginary corresponds to the imaginary in which they are inserted. The imaginary is the mood of a group, a country, a nationstate, a community, etc. The imaginary establishes a bond. It is social cement. Therefore, if the imaginary connects, in the same atmosphere, it cannot be individual. (Ibidem, P. 76)
Such a concept is interesting to understand how social groups appropriate and resignify the urban space through this construction that reproduces what is idealized in the symbolic sphere of the collective imagination.

Still following Maffesoli's theories, Maia (2005) addresses the relation between imaginary, space and celebration, as a vivid realization of space based on the relational historical production of individuals about it. Questioning the relations in spaces, Maia discusses about the "Shared City" (p. 77), which would be, in general, the realization of the aura about space through urban practices.

As the author points out, this type of relation is what would be the action that generates what he defines as "Celebration Spaces". In his view, "celebrations can revolve around the body, sex, image, friendship, comedy, sport, but the important thing is the feeling of local belonging that moves away from global signs" (ibidem, p. 78). Thus, the call for a phenomenological view of social relations is visible, in which experience is placed prominently within the analysis.

Pesavento (2008), starting from the same point of view, defines such spaces as places of memory or places of history, in the sense of representing an absence that, at the same time, is present in memory, a process of reconfiguring time over the meaning space.

\footnotetext{
They are representations that reveal an "event" that, strictly speaking, is no longer verifiable or subject to repetition. But time is no longer irrecoverable, since, through the imaginary, it is present in the spirit, giving itself to read and see through speeches and images. (Ibidem, P. 4)
} 
It is understood that the practical meaning of the production of the collective imaginary about spaces comes from the relations among subjects over the territory in which new meanings are built. Within this perspective, Maffesoli affirms that "the world is a set of reference that I share with the other" (Maffesoli qtd. in Maia, 2005, p. 79), as well as Certeau emphasizes, when he defends that the objective of relations about space it is the experience it provides: "the trivial is no longer the other (charged with recognizing the exemption of its stage director); it is the experience that produces the text " (Certeau, 2014, p. 158).

It is the experience that the individual accumulates that makes them able to produce the meanings about space and, consequently, contribute to the formation of a collective aura about them. Places that have this kind of collective aura in relation to a given social group are those that Maffesoli characterizes as hauts lieux or high places (Maia, 2005).

Spaces like hauts lieux, according to Maia, "are consolidated at different times, by diferente 'spirits' that marked this space" (ibidem, p. 79). These spaces have characteristics of intense agglutination of processes of meaning within the everyday logic, creating a cycle over the cycle; the constant act of daily production by the subjects during history and about space draws the attention of the others who are interested in the place, occupying it and triggering new other processes about the place, thus building a space with symbolic elements and, at the same time, constantly practiced.
Maia quotes some examples from hauts lieux:

In Rio de Janeiro there are many examples of "Hauts Lieux". We can list some of these places of great cultural expression. The imagery of a permanent party in Lapa, downtown; the plurality and charm of Copacabana, sung as "Princesinha do Mar", in the south zone, especially at the end of the year with the great New Year's Eve party, and the daily meetings of the different tribes of the well-known Ipanema beach are also remarkable, for where the famous girl who became a muse for the song translated in several languages around the world circulated. These are points of reference not only for the "carioca", but for the whole world. What especially draws men's attention to these places? We can say that the answer focuses on the capacity of agglutination that these places have. They have a certain "spirit" that contaminates everyone. (Ibidem, p. 79)

In this situation, one can see the dialectical role that the individual has, at the moment when they absorb meanings from the space to build their own identity, and, at a later time, when they use such an acquired identity apparatus to transform symbolic structures present in it, from the reframing process it produces over space.

We can understand more clearly how this relation unfolds from the logic of the neighborhood. Neighborhood is understood here not only as a political and geographical delimitation defined by institutional entities for the division of services, but as a symbolic object constructed socially, in which the individuals 
that inhabit it are much more connected by cultural, identity and relational characteristics (by degree of familiarity with the space and the other subjects that inhabit it).

Regarding the notion of neighborhood, Certeau (2012, p. 39) points out that "the neighborhood appears as well as the place where social engagement is manifested or, in other words: an art of living with partners (neighbors, traders) who are connected to you for the concrete, but essential fact of proximity and repetition ". These two characteristics mentioned by the author, proximity and repetition, can be considered the two main practical elements of the logic of everyday life, considering that the production of meanings about spaces occurs from a process of historical accumulation, having repetition as the tool that consolidates the ideas about the production actions in the face of the signified spaces.

It is, based on the logic of proximity, that individuals from a specific place build ties with the environment in which they live, thus developing a closer affection with certain places that are not seen as places of predetermined logic and functions delimited by an existing social standard. As an example, we can mention the visit of a foreigner to a city that they don't know. As they move through the city, as a subject in the process of accumulating new references, they see the city as a physical object, devoid of the same sensitivity as a resident, due to his relationship of distance with the place. Where this tourist sees a square, the native resident of that place sees, perhaps, an atmosphere of celebration, discussions, meetings or a place referenced by another place - the market square of $\mathrm{Seu}$ José - due to the relationship between these two spaces.

All these meanings appear as a result of the collective production on space, however, they behave as a select knowledge to those who reside there. The individual who does not share these characteristics with the space in which he travels behaves like the intruder who has not been invited to dinner, in which the main dish is the collective memory produced - through repetition and proximity - about the space.

Pollak (1992) works on the concept of collective memory, reaffirming this joint role in which individual identities are suppressed by group knowledge and meanings are not necessarily based on own experience, but on the accumulation and sharing of the symbolic.

First of all,these are events experienced personally. Second, they are the events that I would call "lived by table", that is, events experienced by the group or by the group to which the person feels belonging. These are events in which the person has not always participated but which, in the imaginary, have taken on such importance that, in the end, it is almost impossible for they to know whether they participated or not. (Pollak, 1992, p. 201)

It is the subject in an active, practical way, who builds the environment around it, makes the space a reflection of its identity, and vice versa. It adjusts these spatialities to the group's daily needs, and collective memory is a tool to consolidate this entire process. Regarding this practical posture of the individual about the construction of a meaningful space, Certeau (2012) states that it is the main responsible for the construction of "some urban spaces, from the small town to 
the metropolis, each in our own way, spaces where the modes of active sociability, in the family and at school, in the neighborhood, between neighbors or co-workers" (p. 23).

Therefore, based on sociability, practical statements, this individual qualifies the spaces in which it lives, transits and produces meanings. But how does this subject perform such an action to transform these spatialities, this relationship between being and space? Pointing a perspective, we could say that the daily report is the practical form adopted by the individual in the continuous production of these meanings. It is this account that qualifies, produces memory, poets the city through the differentiation of places, remanufacturing their use, as Certeau (ibidem, p. 45) says "dismantling the chains of the urban apparatus".

\section{Urban rhetoric as a practical enunciation}

Occupying space can also be seen as a form of enunciation and even of building an individual's social identity. Walking through the urban map builds a text that can be read in another way, and that is necessary to understand the discourse of those who make this own rhetoric of this paradigm.

As Certeau (2014, p. 189) states, "everyday reports tell what, despite everything, can be made and done there. They are readings of space". The author works by valuing the act of walking on the city map as a defining element of a legitimate discourse of being. Regarding the concept of city, he defines that

\begin{abstract}
"The city", in the manner of a proper name, thus offers the ability to conceive and build space from a finite number of stable, isolable and articulated properties on top of each other. In this place organized by "speculative" and classificatory operations, management and elimination are combined. On the one hand, there is a differentiation and redistribution of parts according to the city, thanks to inversions, displacements, accumulations, etc; on the other hand, everything that is untreatable is rejected and therefore constitutes the "detritus" of a functionalist administration (abnormality, deviation, illness, death). (Ibidem, pp. 160-161)
\end{abstract}

Based on these assumptions, it is interesting to analyze the way in which this individual attributes meanings to objects and places arranged on the urban space, as well as the way they move over the structure of the city and, from there, observe the relations they weave with the other agents about this environment, legitimizing it.

The city is consumed by individuals through the meanings that are engendered within their social sphere. Regarding how the forms of use make up the construction of an urban text, Certeau explains that:

Down below, from the thresholds from which visibility ceases, ordinary practitioners of the city live. An elementary form of this experience, they are walkers, pedestrians, wandersmänner, whose bodies obey the full and empty of an urban "text" that they write without being able to read it. [...] The networks of these scriptures advancing and intertwining make up a multiple story, without author or spectator, formed in fragments of 
trajectories and alterations, of spaces: in relation to representations, it remains daily, indefinitely, another. (Ibidem, p. 159)

It is, from the report, that the symbolic circulates through space, from the vivid experiences by the subjects, from the experiences shared between individuals who occupy the same space and weave relationships. The report behaves as a transport of meanings that guide the symbolic charges present in the urban environment through the daily activity of the city. Go to work, visit the theater, witness an accident in a certain place, listen to urban legends. All these examples are the elements that constitute the frivolity of the reports, which are recreated every day from the interaction between subjects, spaces and everyday events. Certeau punctuates this issue, making an analogy with the Greek nomenclature for public transport, the metaphorai:

In contemporary Athens, public transport is called metaphorai. To go to work or return home, you take a "metaphor" - a bus or a train. The reports could also have this beautiful name: every day they cross and organize places; they select them and bring them together in one set; make phrases and itineraries. They are paths of space. (Ibidem, p. 182)

In other words, the act of reporting daily life behaves like the experience of a journey over time in a symbolic way, reliving moments from its symbolic effect that produces memory. The reports organize the urban, build everyday life: reports of crime or parties, prejudiced or activist reports, legends from the streets, fantastic stories from the suburbs, all of which are inserted as objects of a democratic management of urban credibility.

The account, therefore, organizes the space in which it is enunciated. A metalinguistic operation of everyday practice. The exercise of orality on the attitude of living. From this act of sharing with others what has been experienced, the process of reframing places occurs, creating aura, drawing a transversal line on the logic of space-time. Certeau also highlights the report as the living spirit of the city, active, that which keeps it alive from the exercise of daily life. According to the author, "a city breathes when there are places of speech, its official function does not matter - the coffee shop on the corner, the market square, the waiting line at the post office, the newsagent's stall, the school gate at the time of way out" (Certeau, 2012, p. 338).

Therefore, let us observe the uses and the meanings produced on the Homeless Population over the city. This group that, despite having a structured enunciation, exposes its identity, its vision and its thoughts through the walks they take on the public environment. The street population attributes to the street not only a space transition value, but also adds a sense of production of meanings, of habitat. It deconstructs the idea of the street as a public limbo among the common spaces of occupation, such as work and family environments. It is, starting from the prerogative of the act of writing with the body in movement, that the PSS makes the street a place of stories. These stories are not only told by language, but by meanings and space. The act of occupying and moving is, in this logic, a way of telling a story and writing one's own rhetoric. 
On the street, one does not seek to listen to reports from the other, the rhetoric of walking consists of practicing continuous reporting, the experience of events in the first person. "The trivial is no longer the other (charged with recognizing the exemption of its stage director); it is the experience that produces the text"(Certeau, 2014, p. 158).

This set of actions and practices demonstrates, according to Certeau, a new paradigm for understanding social logic and the city itself. Perhaps we can say that this view of the city is being carried out in a way by the homeless. It would be a totalizing look at the urban environment.

Escaping the imaginary totalizations of the gaze, there is a strangeness of everyday life that does not come to the surface, or whose surface is only the advanced limit, a limit that stands out above the invisible. In this set, I would like to detect practices that are foreign to the "geometric" or "geographic" space of visual, panoptic or theoretical constructions. These practices of space refer to a specific form of "operations" ("ways of doing"), to "another spatiality" (an "anthropological", poetic, mythical experience of space) and to an opaque and blind mobility of the inhabited city. A transhuman, or metaphorical, city is thus insinuated in the clear text of the planned and visible city. (Ibidem, p. 159)

The city can be understood as the whole of the social body, constituted by the structures, codes, processes and agents that subsist in it. Seeing in such a way, the rhetoric of space behaves like the tool that social agents use to maintain the flow that produces meanings and construction of identities on the plane. Regarding the act of walking in relation to this fluid relationship, Certeau explains that

The act of walking is for the urban system as the enunciation (the speech act) is for the language or for the uttered utterances. Seeing the thing at the most elementary level, it has in effect a threefold "enunciative" function: it is a process of appropriation of the topographic system by the pedestrian (just as the speaker appropriates and assumes the language); it is a spatial realization of the place (just as the word act is a realization, a sound of the language); in short, it implies relations between different positions, that is, pragmatic "contracts" in the form of movements (just as the verbal enunciation is "speech", "puts the other in the face" of the speaker and puts contracts between speakers). The act of walking, therefore, seems to find a first definition as a space of enunciation. (Ibidem, p. 164)

Therefore, the report presents itself as the most important instrument within this process of practical enunciation. It would therefore be the bridge between the experiences lived through the topographic rhetorical processes and the discursive language. The homeless person's report stands as an adjunct to his itinerant discourse, symbolized by the act of walking. The reporting tool is placed as an object that builds the geography of actions, and also as a way of exposing the genuine PSS discourse.

It is interesting to note that the construction of this enunciation process, of the report, is also done by grouping symbols 
obtained within the process of social interaction. It is built from experience, relationship and observations made during the hikes.

Symbols are instruments par excellence of "social interaction": as instruments of knowledge and communication (cf. the Durkeimian analysis of the party), they make possible the consensus about the meaning of the social world. (Bourdieu, 2011, p. 10)

It is important to highlight the relevance that the pure report, the result of the rhetoric of the journey, has to understand the reality of the Homeless Population. Starting from this narrative, which does not exist in any other larger sphere, such as media and governmental, it is possible to understand the true reality of the population living on the streets and their true statements, speeches and visions (about themselves, about society and about the space). As Certeau states, the reports are narrated adventures, which

[...] at the same time they produce geographies of actions and they drift to the common places of an order, they are not just a "supplement" to the pedestrian statements and the rhetorical paths. They are not content to move them and transpose them to the field of language. In fact, they organize the walks. They make the journey, either before or while the feet execute. (Ibidem, p. 183)

To understand the report and its significance is to understand the bridge between the speeches, the statements, the walks and the objectified reality. The discourse is placed in this logic, as something transversal, which runs through the different fields, remodeling itself, which is at a different level, from language, until reaching the "arts of doing".

Based on these reports and speeches, "places of recognition" (Certeau, 2012) or "places of memory" (Pollak, 1992) are constructed. The story organizes the city based on its symbolic construction on spaces. Differentiates, according to Certeau, spaces from places. Or, being broader, in the sense given to the urban, Augé (1997, p. 170) affirms that the city is nothing more than "a combination of places".

Regarding this relationship drawn up by the citizens of the city with this space, it is interesting to pay attention to the definitions proposed by Augé and Certeau about the meaning and attribution of symbolic meaning to spaces. Augé (1997), who works with the relation "place" and "not place", initially defines the idea of "place" starting from arguments that emphasize the identity, relational and historical character that is produced over a given space.

The sphere of identity to which the author refers concerns the way in which the individual builds his socio-cultural background as a recognition tool, with roots that such an individual has towards that place. However, the understanding of this relationship is only possible from the inclusion of the other symbolic spheres, the relational and the historical, which will come to encompass the other characteristics linked to the social relations woven by the individual as a form of social interaction, having the historical element as a guide for all the aura produced in that space. It is referential, as soon as the relations that continue to unfold over that 
spectrum subjectively cause a short circuit over time and space, making the past and present meet through the symbolic contained in the relations. Speaking about the definition of "place" and "not place", the author explains:

By place and not place we designate, it is good to remember, at the same time, real spaces and the relationship that their users maintain with these spaces. The place will be defined with identity (at the moment that a certain number of individuals can recognize themselves and define themselves through it), relational (in the sense that a certain number of individuals, the same, can see the relationship that unites them there to others) and historical (in the sense that the occupants of the place can find in it the different traces of an old implantation, the sign of a affiliation) [...] A space in which neither identity, nor relationship, nor history are symbolized it will be received as not place, but this definition can be applied to a precise empirical space or to the representation that those who are there make of that space. What is a place for some is not a place for others and so on. (Augé, 1997, p. 169)

From this perspective, we can agree with Certeau's view of "space" and "place", which is very similar to Augé's arguments. Certeau works with this perspective, defining "space" and "place" as two symbolic places within the urban environment built by the practice of individuals. According to Certeau (2014, p. 184),

A place is the order in which elements are distributed in relations of coexistence. There, thus, the possibility, for two things, of occupying the same place is excluded. There, the "own" law prevails: the elements considered are next to each other, each situated in a "own" and distinct place that it defines. A place is, therefore, an instantaneous configuration of positions. It implies an indication of stability. [...]. The space is a cross between furniture. It is in a way animated by the set of movements that unfold there. Space is the effect produced by the operations that guide, circumstance, temporize it and lead it to function in a multi-purpose unit of conflicting programs [sic] or contractual proximity.

The differentiation made from the symbolic ordering of spaces and places arranged on the surface of the city's territory is in which we can see, in a practical way, the distinction that individuals and communities make to separate the public from the private, the intimate from the common, the divergence between private human nature, the human condition of public origin (Sennett, 2016, p. 17). The PSS, inserted in this context, taking into account its singular ordering of space, brings such concepts a reinterpretation. The way of living, the ways of distinguishing these two symbolic categories existing on urban space. For the homeless person, the public and the private mix in the same environment, the same can be said about space and place under this path of optics. In this case, we can also list the issue of social segregation over the city space from the point of view of the homeless. It is intended, therefore, to say that the resident, despite being in a public environment, does not always have free access to all his "places". The modern organization of urban space, the preconceived logic about space dictates the elite and degraded areas of the city. Logic arose with the modern city, with functionalist urbanism and, consequently, under the strong influence of capitalism. 


\section{The formation of the concept of urban}

The city, as we know it, has its recent origin. The modern western city, as conceived in Europe, mainly in Paris and London, in the 19th century, can be considered the embryo model of urbanization spread in several other countries, with variations depending on the location and culture of where it is located. To support this statement, Henry Lefebvre, in a critical tone, tends to point out the problems of the Greek city as an impossible project of a perfect city:

Imagine freedom in the century. $X X$ as the freedom of the Greek city (singularly disguised by an ideology: only the city as such had freedom, and not groups and individuals). Therefore, they think of the modern city according to the old city model, identified with the ideal and rational city. The Agora, place and symbol of a democracy limited to citizens and which excludes women, slaves, foreigners, remains, for a certain philosophy of the city, the symbol of urban society in general. (Lefebvre, 2001, p. 47)

However, this model - in relation to the layout of space, the way in which relations are engendered and the way in which the spheres of the public and the private are characterized - popularized by this London or Parisian way of life differed somewhat during the history of society. It is interesting to note the influence that these two models had on the construction and design of Rio's urban space, given that these models stood out as the modern city standard.
Starting with a simple conceptualization of these city models, some that preceded this modern conception of urban living can be listed, and with that also question their meaning, appealing to the dialogical relationship between public and private among this scenario. This means that, in order to understand the meaning of urban, we have to resort to the way the citizens of these cities behaved and understood the public and the private.

The Greek city, one of the first city models dated by history, is still considered, in some aspects, a perfect model that should be adopted in today's society. A city closed in on itself, self-sufficient, with its own code of ethics and formulation of laws. The Greek city-state, specifically archaic Athens, had its notion of public defined by the Agora. This space would be the place for discussion, socialization and the realization of citizenship by individuals in the city, individuals who would be considered citizens, of course. It was the Agora, the place where decisions were made on issues related to the city and its citizens, where codes of conduct were written according to the way in which social agents interact with each other and the urban space. The base of the city was the Agora's direct democracy. However, Sennett (2016) comes to question this democratic notion of the Greek city, exposing how segregationist the notion of citizenship adopted by this society was.

\footnotetext{
Although all citizens, rich or poor, could attend the Agora, most of the ceremonial and political events that took place there were inaccessible to the immense population of slaves and foreigners - Metecos - who supported
} 
the economy of the ancient city. [...]. To immerse yourself daily in this intense and oscillating life demanded that you live close by. However, a large portion of the members of these state cities lived far, beyond the walls, in Khóra; at the end of the 5 th century BC, about $40 \%$ of the citizens lived more than $20 \mathrm{~km}$ from the center, which meant a walk of at least four hours on the roads of the neglected rural region, uneven and full of holes. (Sennett, 2003, pp. 47-48)

Despite the special nature of frequenting the Agora environment, a differentiation between the way of inhabiting the public space and the private way of life has emerged from this context of social relationship. The bond with the other not belonging to the family group, and the sharing of spaces gave rise to what Sennett characterizes as "res public", the public good, without owner and of everyone at the same time. The author explains that

A res public represents, in general, those bonds of association and mutual commitment that exist between people who are not united by family ties or close association, and the bond of a crowd of a "people", an organized society, more than a family or friendship bond. As in Roman times, participation in the res public is today, most of the time, a matter of agreement. (Sennett, 2016, p. 16)

In the mid- $17^{\text {th }}$ century, in the period prior to modernity, the position between public and private is developed, being seen as what is open to anyone's observation. The private, in turn, came to symbolize the region protected from public life, defined by affective ties.
In this way, "public" came to mean a life that takes place outside the life of family and close friends; in the public region, complex and disparate social groups would have to contact ineluctably. And the center of that public life was the capital. (Ibidem, p. 35)

What can be said is that this type of differentiation between these two spatial and symbolic categories was not only defined by the relationships, but also by the attribution of value that individuals performed over the city space, be it public or private. According to Sennett, the private domain was the demarcation point for this notion between the two categories. The author still presents a relationship of nature and culture, with the public as a collective cultural construction (like the Agora codes in ancient Greece) and the private as a space reserved for the human nature of feelings and primitive actions.

In a brief analogy, one can consider that the public environment was human creation, while the private one was the expression of the human condition. Taking into account the collective creation which characterized the public environment, it is interesting to note how the definitions of urban space are partly delimited by them.

The modern city, conceived as a place of interaction and enjoyment of public relations, is shaped from the notions about its "urbanity", which would take into account not only its architectural disposition over space, but also the whole symbolic character linked to itself, built by the relationships that take place there and by the historical process. However, on the threshold of the modern city, 
philosophical currents, such as rationalism, gained space on urban issues, influenced not only by the process of population growth in the city, but mainly by the beginning of the industrialization process, with the advent of the industrial revolution and the growth of capitalism as a financial and political system.

The construction of a city of defined spaces, defined uses and needs was, perhaps, the beginning of this process. As a consequence, the symbolic bias was reduced to private spaces or public spaces where it was allowed (museums, theaters, squares...). French philosopher Lefebvre points out that this urbanist ideology

[...] received increasingly precise formulations, studying the problems of circulation, transmission of orders and information in the great modern city leads to real knowledge and application techniques. To declare that the city defines itself as a circulation and consumption network, as a center of information and decisions, is an absolute ideology; this ideology, which proceeds from a particularly arbitrary and dangerous reduction-extrapolation, offers itself as the absolute truth and dogma, using terrorist means. It leads to the urbanism of pipes, public cleaning, mediators, which is intended to be imposed in the name of science and scientific rigor. (Lefebvre, 2001, p. 48)

The author's criticism is pertinent within the productivist logic, in which capitalism tries to impose itself from this industrialization process from which the modern city is built. An urban reduced to its territory, devoid of meaning and soul, seen as an empty space of meaning. Sennett (2016) presents his critique of this vision of the urban, understanding this process as the contingency of space at the expense of movement. The author argues that this characteristic of the modern city from the beginning of the 19th century permeates to the present day. He states that, within this perspective, "the public space has become a derivation of the movement" (ibidem, p. 30).

To understand this question raised by the author, it is enough to reflect on the relationship of the private car on the urban space of the city. The private car is seen as an instrument of transition between private spaces and thus reduces, as has been said, the significance of the public urban environment, to simple circulation and flow channels. It exposes, as Lefebvre pointed out, the rationalist character as this concept of modern space was conceived. Ideas that determine or seek to determine the type of relationship that the urban citizen must build with their habitat, with the city. The example of the street illustrates this relationship well: it is understood, by this rational urbanism, as a flow space, in which pedestrians and cars have their places demarcated in addition to predetermined directions. The attempt to overcome this logic results in events considered to be dysfunctions. Be it traffic accidents, bumps on the sidewalks, or, more profoundly, the denial of the concept through the act of residing over the place. Functionalist logic disregards the production of these spaces of passage, denying their identity. What there is, in fact, is the partial denial of the urban character of public space, which has the overvaluation of private spaces as a consequence of this reductionism. 
What is clear within all this process of signifying the urban is the influence that industrial capitalism has on the formulation of the symbolic of the city and that, in part, it influences the daily lives of citizens. Therefore, industrialization is understood as a shaping factor of the definitions and paths as the modern city came to build and its peak. As stated by Lefebvre (2001, p. 95), "industrialization provides the starting point for reflection on our time".

Modernity, as Baudelaire wrote in the Painter of modern life (1863), "is the fugitive, the contingent; it is an art half, the other being eternal and immutable (Baudelaire as cited in Harvey, 2014, p. 21). It is in this context of the emergence of new social models that space and individuals are being reformed in the face of the new modern era that was in the 19th century. The remodeling of cities, the development of communication, specifically the strengthening of advertising, which was growing in an unregulated and insane manner.

The industrialization process triggered by the first industrial revolution culminated in the growth of cities, from the population and urban point of view. Modernity gives a new face to the city, creates the metropolis. The urban space is tangent and conceived, now more than ever, due to industrial development. According to Lefebvre,

To present and expose the "urban problem", a starting point is necessary: the industrialization process. Without the possibility of contestation, this process has, for a century and a half, been the engine of society's transformations. If we distinguish between the inducer and the induced, it can be said that the industrialization process is the inductor and that the problems related to growth and planning, issues related to the city and the development of urban reality can be counted among those induced, without omit the growing importance of leisure and "culture" issues. (Lefebvre, 2001, p. 11)

Therefore, we can affirm that the growth of this city, its attributions, is partly a reflection of the needs caused by the industry regarding this new way of living. To Lefebvre, this relationship drawn up with the city by industry is nothing more than a process of exploration in view of production, harmful to urban development in terms of strengthening the symbolic about space

It [the industry] also attacks the city (each city), assaults it, takes it, ravages it. It tends to break through the old nuclei, taking over them, which does not prevent the extension of the urban phenomenon, city and agglomerations, workers' cities, suburbs (with the annexation of slums there where industrialization cannot occupy and fix the available labor). (Ibidem, p. 16)

Through the process of exploring the city, one realizes how the actions of tangentizing the space are engendered, and, as a result, the erasure of the identity traces that citizens could come to build on the place as a form of identification, of identity construction . Regarding the process of development of cities, in view of rationalist urbanism and the capitalism of the economic model, the author exemplifies cities that emerged in such a way and highlights that countries where the 
formation of cities took place by another logic and ended up coming up against depending on the "growth poles".

In France, it would be possible to mention numerous cities submerged by industrialization: Grenoble, Dunkirk, etc., in other cases, there is a massive expansion of the city and an urbanization (in the broad sense of the term) with little industrialization. This would be the case for Toulouse. This is the case in general for cities in South America and Africa, cities surrounded by a neighborhood of slums. In these regions and countries, the old structures dissolve; penniless or ruined peasants flock to cities to find work and subsistence. Now these peasants come from farms destined to disappear due to the set of world prices, which depends closely on countries and industrial "growth poles". These phenomena still depend on industrialization. (Lefebvre, 2001, pp. 17-18)

The role of financial capital in the construction of this urban space is clear, and, from here, in the modern city, we can already understand this as a process of dispute for the imaginary and memory of the city, financially, through attempts to define the way urban life. As the author comes to postulate, such a process can be seen as a class strategy. "Industrialization behaves as a negative power in urban reality: the urban social is denied by the industrial economy" (ibidem, P. 28).

The urbanist school of French origin, with characteristics marked by the planning of space in a planned manner, symbolized in a practical way the existence of intentions, on the part of both the State and the economic power, to model the urban environment under an ideology of capital based on the rationalist logic. Housing estates are the masterpiece of this ideology. Similar urban agglomerations, characterized by sectors limited to specific functions. Place of residence, work and commerce by industry, leisure, etc. The large wide avenues and the empty and wide squares are also trademarks of this model. Just as places are clinically demarcated, so are individuals' activities on them. The objective of these groups, according to Lefebvre, was to demonstrate the greatness of capital and the State's importance in imposing itself on the urban and the daily life of the individuals who lived there.

The baron of Haussman, a man from this Bonapartist state who stands on society in order to treat it clinically as the spoil (and not just as an arena) of power struggles, replaces the tortuous but lively streets with long avenues. sordid but lively neighborhoods with bourgeois neighborhoods. If he opens boulevards, if he arranges empty spaces, it is not because of the beauty of the perspectives. It is to "comb Paris with machine guns" (Benjamin Peret). The celebrated baron does not hide this. Later, they will be grateful to Haussman for opening Paris to circulation. This was not the purpose, the aim of Haussmanian "urbanism". The voids have meanings: loud and strong to proclaim the glory and the power of the State that arranges them, the violence that can unfold in them. (Ibidem, 2001, p. 23)

The squares, in this new model of urbanization and signification of spaces, represent the best example of the symbolic violence carried out by the State against the production of collective memory over the territory. Known as a place of enjoyment, 
interaction and an environment of multiple and undefined activities, the squares were seen as the living hearts of the city. The place where urban living and the practical production of memory were carried out in order to reinforce the sensitive in relationships and to create a vivid local aura. Sennett (2016) points out the reformulations caused by this French urbanism as the justification for the expulsion of collective production from this environment, which, despite being public, should not be practiced as a "place".

[...] the square should be a monument in itself, with restricted activities taking place in its midst, activities consisting mainly of passage and transportation. Above all, these squares were not designed with a slow, congregating crowd in mind. Hardouin-Mansard therefore struggled to eliminate tents, gangs of acrobats and other forms of street commerce from the squares, as well as trying to keep the cafes around him, kept behind doors, and completely removed the inns from the squares. (Ibidem, p. 87)

With this new capitalist logic undertaken over the public spaces of the city, it can be said that there is a clear process of segregation and gentrification taking place in its midst. The elitization of the central spaces of cities based on an urban logic that values the removal of the poor population from the centers, now conceived as objects of contemplation.

Bringing such a discussion to Brazil, we can analyze the case of the city of Rio de Janeiro, observing the process that occurred with the re-urbanization of its central region. Before its valorization process and the consequent elitization, the center of
Rio de Janeiro was largely populated by the tenements, places where, primarily, poor people who migrated from other parts of the country lived, as well as blacks freed from the process of slavery. Cortiço is a cluster of small houses on a single plot and with a single exit. A kind of village, however, with a precarious structure, sometimes without light, sewage and water. With the advance in the growth of cities, the population of these places also increased in number.

Following the model pointed out before by Lefebvre, in Paris, the mayor of the city of Rio, at the time, Pereira Passos, started the process of reformulating the central areas of the city, by widening the streets, revitalizing and creating squares, in addition to modernizing of public services. It was not by chance that his management was commonly known as the "boot below", due to the number of buildings destroyed in the city (Benchimol, 1992).

With the expulsion of the poor from the areas that were beginning to become valued, these individuals began to be thrown into uninteresting areas for the elite: the hills and the exits of cities, away from the lights and leisure of this remodeling city. The street population was also removed from the center, with their housing spaces away from the city. Modernity, in the city of Rio de Janeiro, also brought with it the accentuation of the process of segregation and gentrification over the urban space that was being configured (ibidem).

It is important to note that, despite the modern city, rationalized in its spaces, designed in order to circulate and flow this new large public that inhabits it and makes it 
function as a production gear of the capital market, an attraction escapes from its project model which imposes itself as a space of enjoyment, of meanings and subjectivities over the many new signs that spread in the urban, such as cars and trains, intense traffic, shop windows and desires, products, goods, people, crowd.

\section{The public dwelling of the PSS and the formation of a "private map"}

The contemporary world that presents itself to us is constituted, we can say, by a freedom with respect to the relationships between subjects, spaces and meanings. Such elements are constructed in a much more variable, hybrid way. The individual's own relationship with the urban space, in the sphere of the territory or the symbolic, occurs today, through the mediation of new elements and practices.

All agents have spaces within the social logic. The positioning of each group in the enunciation systems denotes a power relationship between the group that issues the enunciation, the other groups and agents of society and the prevailing preestablished order. It is also considered, based on this assumption, that the place exercises power over said speech. Such influence alters the importance and the visibility given to it. As an example, we can give the differentiations between the institutional discourse - of the governors,
State authorities -, the media discourse of the media, the discourse of the business economic sector, the discourse of public opinion and the discourse of minority groups in society - classes disadvantaged groups, leftist dissident political movements, ethnic groups and the Homeless Population itself, which is composed as a possible class and can also be dissolved in other groups.

Institutional discourses can be considered one of the models of hegemonic discourse within the social sphere. In this way, it can be analyzed precisely in terms of the elements contained in society that support its credibility, such as the political structure more clearly. Therefore, one sees, in this way, the importance that the environment in which the speeches are produced has, symbolically, about this mechanism. The social capital that it emanates for those who exercise the act of enunciating.

In the case of rhetorical models observed in the media, economic and political spheres, one can observe a non-generalization of this sector, as soon as they move between the hegemonic and the counter-hegemonic. Regarding the concept of hegemony, Gruppi explains that

A class is hegemonic, ruling and dominant until the moment when through a class its political, ideological, cultural action - manages to keep articulated a group of heterogeneous forces and to prevent the existing contrast between such forces from exploding, thus provoking a crisis in dominant ideology, leading to the rejection of such an ideology, a fact that will coincide with the political crisis of the forces in power. (Gruppi, 1978, p. 67) 
Finally, minority groups in society have a discourse that does not have the same social, political and ideological relevance due to their position within the infrastructure in question and, consequently, the accumulation of objectified social capital.

Thus, the attempt to regulate the speeches issued by social groups is exposed. The discourse, in this situation, engenders a relationship of power, of overlap between groups, a structure of symbolic dispute. Regarding the discourse in society, Foucault postulates:

In every society the production of discourse is simultaneously controlled, selected, organized and redistributed by a number of procedures whose function is to conjure up its powers and dangers, to dominate its random event, to evade its heavy and fearful materiality. (Foucault, 2012, pp. 8-9)

The materiality put forward by Foucault refers to the way power relations are built from discourse. This power relationship is based on the interaction of individuals with the existing symbolic structures using the discourse tool. In its speech, PSS could have elements that could alter its symbolic and perhaps even social and economic condition. Due to this regulation of discourse, the society in which we operate is based on such a structure and, therefore, the places that each agent must place itself.

Another explanation for the restriction of the speech power given to the PSS would be to see the discourse, in addition to its power function, as a communication tool for social interaction of individuals. However, as Bourdieu argues, the relation between communication and the structuring structures of power is inseparable.
Against all forms of "interactionist" error, which consists of reducing power relations to communication relations, it is not enough to note that communication relations are, inseparable, always, power relations that depend, in form and content, of the material or symbolic power accumulated by the agents (or by the institutions) involved in these relationships and which, like a gift or polatchi, can allow to accumulate symbolic power. (Bourdieu, 2011, p. 11)

Therefore, exclusion procedures also affect the region of minority speeches, specifically that of the homeless. The act of denying the space of speech or devaluation, due to the enunciation position, is characterized as an element that reinforces the actions linked to the process of social exclusion. Among these actions, we can list as ways of interdicting speech, in addition to denying speech, the discrediting of rhetoric due to madness or elements that are external to the enunciation, but still referring to the condition of the individual who produces the narrative

In a society like ours, we know, of course, exclusion procedures. The most evident, the most familiar too, is interdiction. It is well known that one does not have the right to say everything, that one cannot speak of everything under any circumstances, that anyone, in short, cannot speak of anything. (Foucault, 2012, p. 9)

The PSS discourse can be understood as a banned discourse, as soon as the visibility and support given to this group are very small. An example of this are the opportunities given by sectors, structures and some social agents. 
When issues related to this group arise, the speech that is enunciated usually comes from outside. Whether it is the media talking about street dwellers and their ills before society, or the government presenting PSS as a social malaise that must be resolved. There are also the cases of Non-Governmental Organizations (NGOs) that conduct temporary assistance actions to this group, such as the distribution of food and clothing.

To illustrate the cases of welfare actions carried out by NGOs, let us see the action of distributing the famous soup to people who are considered to be in need: the resident is not asked if they want what is distributed to them as something subjectively imposed. Their condition of alleged misery denotes that they have no choice, their rhetoric does not matter when they have no other option. The discourse of choosing something different is invalidated, due to the position in which it was placed as disadvantaged.

In addition to the concepts already exposed to explain this process of denying the PSS discourse, we can point to madness as a symbolic devaluation of what is said. According to Foucault, "The crazy is that speech that cannot circulate like that of others: it may happen that its word is null and is not accepted, having neither truth nor importance" (ibidem, p. 10).

The relation that can be made between the speech of the individual classified as crazy and the speech of the homeless person begins with the characteristics of the devaluation of the enunciation, but it is not reduced to this. In view of the current society and the established ethical, moral and social standards, these two examples are characterized as something that does not obey this imposed logic.
The madman is seen as such due to the disconnection from what he says and the way of acting in the face of reality. The homeless person resembles the classification model of the madman with regard to the way of acting they don't have the same action as one person characterized as mad, but their conduct is analyzed as inconsistent with that of the current social norm - because it fits existing paradigms of coexistence and collective experience. Therefore, they build a new model on himself, a new "way" to behave within the system. Such an initiative can be characterized as a form of social struggle, attempting to empower your own discourse or validating it. According to Foucault, "the discourse is not simply that which translates the struggles or systems of domination, but that by which, for what one fights, the power that we want to seize" (ibidem, p. 10).

It is noticed that the struggle for power within the discursive scope is something latent. In the cases of private minorities obtaining their own discourse, they sometimes take over external discourses as if they were their own, for the sake of representativeness within the existing social system. It is characterized as another aspect besides the ideological dispute for empowerment, of a genuine discourse that would be the alienation of the discourse that the individual enunciates.

Such an issue seen from the perspective of the PSS is characterized at the moment when the resident, devoid of their own speech about his condition, adopts the idealizations created by other sectors of society to characterize them. It adopts a discourse external to itself in order to describe itself and understand its reality - while protecting its discursive rhetoric as a form of identity conservation --, with 
the aim of facilitating its acceptance before the existing social context, since what the enunciation that the individual elucidated is considered, in some cases, invalid.

The speech is nothing more than the reverberation of a truth being born before your very eyes; and, when everything can, at last, take the form of discourse, when everything can be said, discourse can be said about everything, this is because all things, having manifested and exchanged their meaning, can return to the silent interiority of self-awareness. (Ibidem, p. 46)

From this point, the discussion about the discourse emitted by the PSS is raised in some cases, trying to differentiate when the discourse that is pronounced is proper or displaced, assimilated from another social agent or structure. On this model of reproduction of enunciative ideas, Bourdieu postulates that

If the relations of objective forces tend to reproduce in the visions of the social world that contribute to the permanence of these relations, it is because the structuring principles of the world view are rooted in the objective structures of the social world and because the relations of power are always present in consciousnesses in the form of categories of perception of these relations. (Bourdieu, 2011, p. 142)

Therefore, seeking to deviate from this discursive reproduction that may happen to what is enunciated by the street population, another way of understanding enunciation is sought, which is more distant from the influences that produce the dominant structures of society and their respective agents: walking around the city.

Ambulatory rhetoric, as defined by Michel de Certeau, would be another form of enunciation within the social system. The author traces relationships between space and text, movement and enunciation. The act of walking would be another freer way of giving a speech about space, suffering less influences from the dominant structures. Certeau defines such thinking, stating that

There is a rhetoric in the walk. The art of shaping phrases has as an equivalent the art of shaping paths. Like the ordinary language, this art implies and combines styles and uses. The style specifies "a linguistic structure that manifests on the symbolic level [...] the way of being in a man's fundamental world". It connotes a singular. Usage defines the social phenomenon by which a communication system actually manifests itself: it refers to a norm. Both style and usage aim at a "way of doing" (speaking, walking, etc.), but as a singular treatment of the symbolic, the other as an element of a code. They intersect to form a style of use, way of being and way of doing. (Certeau, 2014, p. 166)

Therefore, in order to fully comprehend the enunciative act of these individuals, it is necessary to understand the discourse written about space in its "ambulatory" form, through the use and occupation that it outlines about the physical and symbolic space.

The walk behaves not only as a practical discourse on the territory, but also as the way that the individual builds their own meanings 
on the space they travel. They attribute specific meanings, based on their experience with the urban environment, producing a specific daily logic. It would be, then, the production of a mental map, which would carry symbols and information collected by the individual from their practical experiences with the urban environment in which they are inserted. In other words, it would be their urban trajectory.

\begin{abstract}
Unknown producers, poets of their businesses, inventors of trails in the jungle of functionalist rationality, consumers produce something that resembles the "lines of error" that Deligny talks about. They trace indeterminate "trajectories", apparently meaningless because they are not consistent with the built, written and prefabricated space in which they move. They are unpredictable phrases in a place ordered by systems organizing techniques. (Ibidem, p. 91)
\end{abstract}

The homeless person, from this process, transforms this space, resignifies and creates history about it; their walk write, on the urban fabric, their identity that has been constituted there. It would translate, perhaps, the vision exposed by Simmel about what space is: "Space in general is just an activity of the soul, just the human way of joining sensory stimuli that are disconnected in unitary visions" (Simmel, 2013, p. 76).

A "private" map is designed from the point of view of the person who experiences it; the act of dwelling placed here as a tool that produces meaning, a particular singularity of the individual, in this case, of the homeless person, which transposes the logic of dwelling and habitat established by the social order of the urban space in which it is inserted.
It is interesting to notice the way these practices take place for the production of this new land described here as a map of the mapped urban space. The homeless act on the other's territory, as a way of living and surviving, creating their own logic. Their action, according to Certeau, is everyday tactics, the strength of the oppressed, the cunning of the weak in the place that is external to them, which is not their own.

\begin{abstract}
[...] I call tactics the calculated action that is determined by the absence of one's own. Therefore, no delimitation from outside provides the condition of autonomy. The tactic has nothing but the other's place. That is why they must play with the land imposed on them as organized by the law of a strange force. It has no means of maintaining itself at a distance, in a position of retreat, of foresight and of its own calling: the tactic is movement "within the enemy's field of vision", as von Bulow said, and in the space they control. (Certeau, 2014, pp. 94-95)
\end{abstract}

The subject who resorts to everyday tactics is the one who is powerless, having their actions as something unplanned, spontaneous, in the form of resistance to the pre-established, calculated, strategic logic. It is very similar to the life model of the street population, subjugated to living under the jurisdiction of a State strategy, of social institutions that, in some way, have influence over the way this territory is signified. The author points out that "tactics are determined by the absence of power" (ibidem, p. 95), placing it in opposition to strategy, calculated practices exercised over the environment by the spheres of social power. 
Although we understand this set of experiences acquired by the individual regarding the space in which they find themselves as the formulation of a map from this tactical stance, we have to place this element as a result of the interaction process between being and the environment. What we seek to expose, based on this statement, is the fact that the production of this repertoire occurs through tactical action, through the logic of the route, presented by Certeau (ibidem).

Similarly, the author exposes the relationship of map and route as one, the practical process and the other, theoretical. How seeing and doing, inhabiting and narrating. The route, within the scope of the analysis of the street population, would be their pure way of living and relating to the urban environment, while the map, the construction on the memory acquired by these interactions over space. The particularity of this dwelling makes the process of creating maps, through the execution of the paths, a fact that constitutes the identity of these individuals, who not only resignify the space, but also use this same space to resignify themselves.

\section{[I] https://orcid.org/0000-0001-8491-9660}

Federal Fluminense University, Human Sciences and Philosophy Institute, Anthropology Postgraduate Program. Niterói, RJ/Brazil.

lucasvlfsa@gmail.com

Translation: this article was translated from Portuguese to English by Patricia Souza ptrc.sousa.santos@gmail.com 


\section{References}

AUGÉ, M. (1997). “Novos mundos”. In: AUGÉ, M. Por uma antropologia dos mundos contemporâneos. Paris, Bertrand Brasil.

BENCHIMOL, J. L. (1992). Pereira passos: um haussmann tropical. A renovação urbana na cidade do Rio de Janeiro no início do século XX. Disponível em: <http://www.rio.rj.gov.br/ dlstatic/10112/4204210/4101387/pereira_passos_haussmann_carioca.pdf>. Acesso em: 7 mar 2018.

BourdieU, P. (1997). "Efeitos de Lugar". In: BOURDIEU, P. (org.). A miséria do mundo. Petrópolis, Vozes.

(2011). O poder simbólico. Rio de Janeiro, Bertrand Brasil.

CERTEAU, M. de (2012). A invenção do cotidiano: morar, cozinhar. Petrópolis, Vozes. (2014). A invenção do cotidiano: artes do fazer. Petrópolis, Vozes.

FOUCAULT, M. (2012). A ordem do discurso: aula inaugural no Collége de France, pronunciada em 2 de dezembro de 1970. São Paulo, Edições Loyola.

FREITAG, B. (2012). Teorias da cidade. Campinas, Papirus.

GRUPPI, L. (1978). O conceito de hegemonia em Gramsci. Rio de Janeiro, Graal.

HARVEY, D. (2014). "Espaços e tempos individuais na vida social”. In: HARVEY, D. Condição PósModerna. São Paulo, Edições Loyola

LEFEBVRE, H. (2001). O direito à cidade. São Paulo, Centauro.

MAFFESOLI, M. (2001). O imaginário é uma realidade. Revista Famecos. Porto Alegre, n. 15, pp. 74-82.

MAIA, J. (2005). Michel Maffesoli e a cidade partilhada. Revista Famecos. Porto Alegre, n. 26, pp. 77-85.

PESAVENTO, S. J. (2008). História, memória e centralidade urbana. Revista Mosaico, v. 1, n. 1, pp. 3-12.

POLLAK, M. (1992). Memória e Identidade Social. Estudos históricos. Rio de Janeiro, v. 5. n. 10, pp. 200-212.

SENNETT, R. (2003). Carne e pedra: o corpo e a cidade na civilização ocidental. Rio de Janeiro, Record. (2016). O declínio do homem público: as tiranias da intimidade. Rio de Janeiro, Record.

SIMMEL, G. (2013). Sociologia do espaço. Revista Estudos Avançados. IEA-USP, n. 27, pp. 75-112. 
